\title{
HISTORICAL RETROSPECTIVE OF GENDER PROBLEMATICS PROGRAM
}

\author{
Matvienko I. S., PhD, teacher Faculty of Humanities and Pedagogy \\ Department of Philosophy, \\ National University of Life and Environmental Sciences of Ukraine \\ E-mail:malushka20@ukr.net
}

\begin{abstract}
While considering historically gender problematic of woman and man we can observe individual differences and their becoming in family and social life. It's important to understand that gender problematic has historical character, which constantly changes in the process of development. The main goal of the paper is to consider the evolution of gender problematic in the context of the development of history of philosophy.
\end{abstract}

Key words: man, woman, gender, family, society

Introduction. After gaining its independence the Ukraine has set out on course toward equality between women and men and tries to introduce gender component almost in all the spheres of social interaction, which is reflected not only in normative documents but also in gender programs, which are aimed to approach this question from practical standpoint. While considering historically gender problematic of woman and man we can observe individual differences and their becoming in family and social life. It's important to understand that gender problematic has historical character, which constantly changes in the process of development.

Analysis of recent researches and publications. The exploration of the problem of gender problems which arise in the relations of men and women has its origin in the works of the thinkers of Ancient Greece, Plato and Aristotle to be precise, who had began in their works to consider the question of relations between men and women, in family as well as in society in general. Every historical epoch gives us a model according to which men and women are supposed to interact. Nowadays this theme is to a certain extent widely explored and actual and starting from the middle of XIX century we can see the constant flow of new works dedicated to these problems.

Purpose. The main goal of the paper is to consider evolution of formation of gender problems in in the context of the development of history of philosophy.

Results. When we consider the antique period of the genesis of gender studies the names of Plato (427-347 b.c.e.) and Aristotle (384-322) should be mentioned. For example, in his work «Simposium» Plato writes about three sexes: men, women, and androgines. Plato uses in his works the myth about androgines (from Greek word Andros - man, gyne or gynaikos - woman). «Firstly, notwithstanding, we should get to know something about human nature and things which have happened to it. There was a time when our nature was not the same as now but drastically different. First of all, people had three sexes and not two, as today - male and female- cause there existed third sex which joined in itself the name and appearance of both sexes male and female... And there were three of those sexes and such they were because male from beginning arise from the sun, female from the Earth an joined two of them the Moon cause Moon unites both powers...At last Zeus said: «it seems that I have found the way to protect people and 
at the same time to put the end to their extremities by reducing their power. I will put all of them in half and they will become weaker and at the same time more useful for us cause their quantity will increase... Men which represent only one part of that which contains two sexes of the first entity which was called "androgin," who had passion towards women... those were creatures who had in themselves features of both woman and man. Zeus was mad at them and divided them into two halves of the same whole, and only when they would fall in love with each other can act of wholeness be accomplished» [6].

Later, in his another work «The Republic» Plato formulated his own vision of gender models, in particular he suggests the models of behavior of men and women. In Plato's view women and men shouldn't merry at their whim, so neither man nor woman has the right to choose which makes them equal. It appears that marriage is secretly guided by philosophers who unite the best ones with the best ones and the worst ones with the worst .After childbirth children after some time are taken away and then they are given to different mothers and no one knows whose child is given to whom and all the men (in the margins of cast) are considered to be fathers of all the children and all the woman to be wives of all the men.

For Plato common ownerships of wives and children is the highest form of unity of human beings. He formulated an ideal construct although in real life he was a man of his own time and correspondingly he was influenced by the stereotypes of Antiquity concerning relation toward woman in which woman was considered to be lower than man. Thus he said, that if «a man was a coward during his life than after death his soul will be converted into a woman». On the other side in his work "The Republic» gives to woman equal rights with man, so she can be even a philosopher or a warrior while childrearing is responsibility of both sexes.
The resolution of gender problems by Aristotle is different from Plato's as he considers woman to be equal to man but he believes her to be a slave and he strives to give an answer to the woman question by considering in his "Politics» two dimensions of womanhood: woman as a part of family and as a part of society in general. On the level of society woman is not equal to man as she doesn't have those qualities which are essential to man (bravery, courage, kindness, modesty, moral virtues) although some of them (kindness, moral virtues, modesty, justness) can belong to a woman but to a far lesser degree. "So the power over wife and children exists as over free people but it is performed in different ways... a slave can't think at all but a woman can do it but this ability doesn't find an application.. The expression "Silence is a decoration" can be applied to all the women but not to men» [1,p 33-34]. But on the level of family woman is equal in importance, but with different functions which are essential to her. Man actively realizes himself outside of home i.e. in politics, and his main function is to provide for his family. Woman who has as much importance for family as man is destined for housekeeping while her function is to protect and multiply the gains of man. We should note that in relation to continuation of species Aristotle gives priority to man as from man child receives form and from woman only matter. And in the work «About genesis of animals» Aristotle notices that woman is a sterile man.

For the Middle Ages there were two main factors which determined the relation to gender problems: on the one side, bible history and on the other, medieval society with its norms and believes. It is written in the Bible: "And God said, Let us make man in our image, after our likeness: and let them have dominion over the fish of the sea, and over the fowl of the air, and over the cattle, and over all the earth, and over every creeping thing that creepeth upon the earth...So God created man in his own image, in the image of God created he him; male and female created he them"

(c) Matvienko I.S.

HUMANITARIAN STUDIOS: PEDAGOGICS, PSYCHOLOGY, PHILOSOPHY Vol 10(3) 2019 
[Genesis 1:26,27]. So in the beginning God created man and woman as a unified whole. The paradisiacal life of man and woman and direct communication with God haven't had hierarchical character which appeared after the Fall as both man and woman are creations of God. Hierarchy and other forms of inequality arises in medieval society with appearance of apostles who thought in margins of typical to this times, mainly antique culture, and their interpretation of the teaching about the hierarchy of divine creatures. In society there existed great difference between woman and man. Although woman already had right for education but she wasn't allowed to take part in government cause there was no mention of gender equality in society. Only man can be a head of church and state and whole society must be obedient to him. In this common subjugation to higher power equality was displayed. All the rights disappeared due to particularism as there was no equality of rights, rationality of laws aimed to the whole, to state. The institute of family existed but desires of woman were not considered.

In the epoch of Renaissance the culture was formed on the basis of Antiquity, so of great interest are utopias. Of special interest are the works of Thomas More (1478-1535) "Golden book" where he describes an ideal state and "The city of the sun" by Tommaso Campanella in which the idea of the ideal city is proposed. T.More considers the activity of the man and the woman as such that can be equal independently of the sphere whether it is science, art, religious activity or even military service (although only together with a man). Highest positions in the state can be held by both men and women, family must be built not on the basis of love but on the harmony of characters where family pairs are determined by parents. In the same way first gender problems begin to be formed: equality of abilities of man and woman for different occupations, education and leadership.
A utopian Tommaso Campanella speaks about indivisibility of education and upbringing as for man so for woman (including military art) the clothes is not sexually differentiated as well. But their occupations are different so the woman should concentrate on childbirth and the man should perform hard physical labor. Although in his ideas the institute of family is absent, but in general the ideas of T. Campanella can be interpreted in this way: equality of genders while resemblance of clothes corresponds to resemblance of characters, thoroughly regulated gender roles and privileges of rule for women: "All heads of detachments - both male and female ones... childbearing is in interest of the state and interests of persons are important only because they are parts of the state ... Breastfeeding is a responsibility of female heads of detachments if it is a girl and of male heads of detachment if it is a boy" [3]. In the epoch of Renaissance the return to ideas of Plato was going on cause in the problem of gender relations nothing new was suggested.

In the XVIII century in the works of G. Locke and T. Hobbs arises the idea of "the social contract" in which they determine chief grounds of equality of all the citizens as before XVIII century the woman was considered to be equal to the man. But the idea of social contract has shown that social and gender equality can exist. Further we can trace the development of gender ideas in the work of Jean-Jacques Rousseau (1712-1778). While analyzing resemblance and difference in the norms of behavior between men and women (that was called in the modernity "gender stereotypes") he also thought about particularities of education of both women and men and of relations in the family. In opinion of the thinker equality and resemblance between men and women rises up first of all from their biological resemblance as representatives of humankind. But as social creatures they are unequal which is explained by their innate characteristics. Correspondingly there are different norms

(c) Matvienko I.S.

HUMANITARIAN STUDIOS: PEDAGOGICS, PSYCHOLOGY, PHILOSOPHY Vol 10(3) 2019 
of behavior: the man is open, direct, conscientious, has his own judgments, sincere when the woman is shy, cunning, flirtatious, considering the thoughts of other people. In this way Russo views moral virtues of different sexes. On the question of education he wrote that the woman has sophisticated and shrewd mind that is why she is capable to get education and not only in the matters of housekeeping and child upbringing but in other spheres too.

Immanuel Kant (1724-1804) differentiated between men and women first of all on the character of participation in political activity and then on the character of individuality and behavior. Men are active in decision making and women are passive. Some traits of women are connected with childbearing but also she is moral, eloquent, reasonable, timid and with expressive face. Gender stereotypes which were expressed by Kant rule even today in the political circles (woman isn't capable to make important political decisions) and basic women's characteristics are connected with biological and cultural status of the woman. An English writer Merry Wollstonecraft (1759-1797) expressed the thought that natural characteristics are connected with upbringing (today it is called gender socialization).

Although there were various thoughts in different epochs and countries we can still notice their contemporary echo. It is important to notice that these researches don't have the character of the finished system but they give the vectors for further development in XIX, XX and XXI centuries. In the end of XIX and in beginning of $X X$ centuries in many western countries the social situation is changed . In the Great Britain, France and in the United States the movement for women's rights took toll, feminism got started (in the first part of XIX c.) an great multiplicity of currents and declarations arose which stood for the rights of the woman for freedom of choice, work, education and so on.

For XX century the figure of Sigmund Freud became symbolic who was the first to explore women's consciousness. While exploring women consciousness he wrote works like "Womanhood", "Psychology of women" and other, developed the theory of narcissism both for women and for men and considered their sexual relations. XX century had drastically changed the relation toward gender stereotypes and talk of equality gained new meaning.

On the modern stage of the development gender relations became the object of psychological research. There are four types of sex roles which are common both for men and women: male, female, androgin and undifferentiated. Human becomes identical to him- or herself only when he or she has both male and female characteristics. Gender identity signifies that a person accepts determinations of manliness and womanhood which are common to her culture. Of greatest importance in this process is the way of subjective self-categorization of a person.

In the last ten years swiftly develops realization of ideas of gender approach to education and creation of gender orientated system of education. Such system of education takes into consideration psychological particularities of the development of individuals on different stages of education and this helps to harmonious personal development in connection with gender and creates the conditions for maximal self-realization and development of abilities of boys and girls. Such system creates the conditions for personal development and for improving of psychological health of pupils thanks to the principles of separate education, provides possibilities turn boys and girls into individuals capable of interaction with each other and with society in general.

Conclusions. So gender is socio-psychological sex of a person, the entirety of his or her psychological characteristics and particularities of social behavior which is displayed in communication and interaction. It is obvious from this definition that in difference to biologically predetermined sex "gender" is a psychological and

(c) Matvienko I.S.

HUMANITARIAN STUDIOS: PEDAGOGICS, PSYCHOLOGY, PHILOSOPHY Vol 10(3) 2019 
social category both of those aspects are developed to different extent in the result of personal education. And the most important role in the formation of socially mature person is played by parents and teachers.

\section{References}

1. Aristotel'(2000) Polityka [Politics] / Per. z davn'ohr. ta peredm. O. Kyslyuka. K.: Osnovy, 239.

2. Bibliya (2004) Knyhy Svyashchennoho Pysannya Staroho i Novoho Zavitu: v ukrayins'komu perekladi z paralel'nymy mistsyamy [The Bible. Books of Scripture of the Old and New Testaments: in Ukrainian translation with parallel places] / Pereklad Patriarkha Filareta (Denysenka). K.: Vydannya Kyyivs'koyi Patriarkhiyi Ukrayins'koyi Pravoslavnoyi Tserkvy Kyyivs'koho Patriarkhatu, 1416.
3. Campanella, T. City of the Sun. Available at: http://lib.ru/INOOLD/KAMPANELLA/suntown.txt

4. Matviyenko I. (2012) Lyudy'na yak predmet filosofs`kogo osyagnennya (ploshhy'na filosofiyi Erixa Fromma [Man as the subject of philosophical comprehension (the plane of philosophy of Erich Fromm)]// Mul'ty versum. Filosofs`ky’j al'manax / Gol. red. Lyax V. V. Vy’p. 2 (110). K. S. 80 - 94.

5. Matviyenko I. (2014) Suchasna religijno-social'na oriyentaciya lyudy`ny` $v$ sviti (filosofs`ky'j poglyad E. Fromma) [Modern religious and social orientation of man in the world (philosophical view of E. Fromm)]// Gileya: nauk. visny`k: zbir. nauk. pracz'. K. : PP «Vy`davny”cztvo «Gileya». 86 (7). S. 247 $-250$.

4. Plato Peer. Available at: http://lib.ru/POEEAST/PLATO/pir.txt

\section{ІСТОРИЧНА РЕТРОСПЕКТИВА ГЕНДЕРНОЇ ПРОБЛЕМАТИКИ Матвієнко І. C.}

Анотація. Розглядаючи історично гендерну проблематику жінки та чоловіка ми можемо простежити індивідуальні відмінності та становлення їх в сімейному та суспільному житті. Важливим є розуміння того, що гендерна проблематика носить історичний характер, який постійно знаходиться в процесі розвитку. Основною метою статmі виступає розгляд еволюції формування гендерної проблематики в історико-фрілософьському процесі. З'ясовано, що в останні десять років стрімко розвивається реалізація ідей гендерного підходу до освіти і створення гендерно-орієнтованої системи освіти. Така система освіти враховує психологічні особливості розвитку індивідів на різних щаблях освіти, що сприяє гармонійному особистісному розвитку і створює умови для максимальної самореалізації та розвитку здібностей особистості як чоловічої, так і жіночої статі. Така система створює умови для особистісного розвитку і поліпшення психологічного здоров'я учнів, надає можливості хлопчикам і дівчаткам ставати особистостями, здатними взаємодіяти один з одним і з суспільством в цілому. Стать розглядається як соціально-психологічна характеристика людини, сукупність його або ї̈ психологічних характеристик і особливостей соціальної поведінки, які проявляються в спілкуванні і взаємодії. 3 цього визначення очевидно, що на відміну від біологічно визначеного сmami «стать» $є$ психологічною і соціальною категорією, обидва ці аспекти в різному ступені розвиваються в результаті особистого виховання. Найважливішу роль у формуванні соціально зрілої людини відіграють батьки та вчителі.

Ключові слова: чоловік, жінка, рівність, гендер, сім `я,суспільство. 